\title{
Legal and economic dilemmas of sustainable development in times of global crisis*
}

\section{Prawne i ekonomiczne dylematy zrównoważonego rozwoju w dobie ogólnoświatowego kryzysu}

\author{
Maciej Rudnicki \\ The Faculty of Law, Canon Law and Administration, Catholic University of Lublin, Poland \\ ORCID: https://orcid.org/0000-0002-0019-3469•kancelaria.rudnicki@poczta.fm
}

\begin{abstract}
The starting point for the reflections were a range of issues bordering philosophy, morality, economy and law, regarding the rational management of natural resources and protection of the natural environment, as well as the regulation and forming of peoples' attitudes and behaviours in relation to the natural environment, and the setting of legal boundaries for those behaviours and sanctions for crossing them. The state of the natural environment has a very strong influence on the fulfilment of existential human needs. Humans strive for satisfactory life of appropriate quality, and often have to make choices between various goods. Unfortunately, ecological properties are very often treated last of all in the decision-making hierarchy, and are usually considered inferior to, for example, material prosperity or social comfort. Treating the ecological properties as such, often results in them going unnoticed overall, and very soon leads to permanent and negative changes that directly affect human life and the environment, as well as having a negative effect on health. Therefore, such extraordinarily essential conditions for choosing and fulfilling ecological needs as regards first-class existential needs that have a vital influence on the quality of life and ecological awareness, are based chiefly on understanding the rules of sustainable development. Should the development of civilisation be ruled by economy, or should the basis of that development be protection and maintenance of natural environmental resources? Or maybe the most sensible option is to balance economic, social and ecological aims? The problem pinpointed in this way highlights the importance in life of global community, and may for years induce consideration and reflection.
\end{abstract}

Keywords: sustainable development, quality of life, ecological crisis, economy

Streszczenie: Rozważania prowadzone w niniejszym artykule wychodzą od szerokiego zbioru zagadnień z zakresu filozofii, moralności, ekonomii i prawa odnoszących się do racjonalnej gospodarki zasobami naturalnymi, ochrony środowiska naturalnego, a także formowania ludzkich postaw i zachowań wobec niego; wreszcie ustanowienia prawnych granic tego odniesienia i sankcji za ich przekroczenie. Stan naturalnego środowiska ma istotne znaczenie dla zaspokojenia życiowych potrzeb człowieka. Ludzie dążąc do osiągnięcia satysfakcjonującego ich poziomu życia, odpowiedniej jego jakości muszą wybierać między wieloma różnymi dobrami. Niestety, wartości ekologiczne widziane są często jako mniej istotne i przy podejmowaniu decyzji przegrywają z dążeniem do posiadania majątku czy społecznego komfortu. Takie traktowanie dóbr ekologicznych skutkuje niedocenianiem ich i prowadzi do negatywnych zmian w środowisku, mających także negatywny wpływ na życie ludzi. Tworzenie warunków zaspokajania podstawowych ludzkich, kształtowania jakości życia, potrzeb powinno opierać się na zrozumieniu zasad zrównoważonego rozwoju. Czy rozwój cywilizacyjny ma kierować się wyłącznie względami ekonomicznymi, czy też jego podstawą powinno być zachowanie zasobów naturalnych? Czy może najrozsądniejszą opcją jest znalezienie równowagi w dążeniu do ekonomicznych, społecznych i ekologicznych celów? Omawiany problem ma charakter globalny i wciąż powinien prowadzić do pogłębionej refleksji.

Słowa kluczowe: zrównoważony rozwój, jakośćżycia, kryzys ekologiczny, ekonomia

\footnotetext{
"This article was originally published in Polish as Rudnicki, Maciej. 2009. „Prawne i ekonomiczne dylematy zrównoważonego rozwoju w dobie ogólnoświatowego kryzysu." Studia Ecologiae et Bioethicae 7(2): 61-72. The translation of the article into English was financed by the Ministry of Science and Higher Education of the Republic of Poland as part of the activities promoting science - Decision No. 676/P-DUN/2019 of 2 April 2019. Translation made by GROY Translations.
} 


\section{Introduction}

The principle of sustainable development, adopted in the Constitution of the Republic of Poland (Article 5), is the leading principle of the Polish environmental policy. The principle, developed in 1987 in the so-called Brundtland Report of the World Commission on Environment and Development (UNCED), was recognised by the international community as a model of socio-economic development and conduct in environmental matters in 1992, at the United Nations Conference on Environment and Development, held in Rio de Janeiro $^{1}$. The basic assumption of sustainable development is the implementation of policies and activities in particular sectors of the economy and social life, which leads to the preservation of resources and values of the natural environment in a condition ensuring permanent, undisturbed opportunities to use them, both by present and future generations, while maintaining the sustainability of natural processes (Przyborowska-Klimczak 2004, 25) and natural biodiversity (Leroy 2000, 9). The importance of sustainable development is the equal treatment of social, economic and environmental rationale, which involves the need to integrate environmental protection issues with policies in individual areas of the economy (Maśniak 2003, 21).

\section{Fundamental dilemmas}

People living in the 21st century, now in the era of global financial and economic crisis, often have to make choices between values or goods, based on their minds, beliefs, experience, and a variety of world views. However, they should ask themselves about the hierarchy of values and goods and the mutual relations between them. What is more important: prosperity or peace, health or education, economic development or environmental protection? Do absolute values exist, and if so, what are they: the life of an individual or

1 The Rio de Janeiro Conference also adopted the Global Action Plan for Environment and Development in the 21st Century (Agenda 21); (L. Móller 2004b, 217; Agenda 1998). the development of the entire community?

Modern man, both in individual and social aspects, is entangled in various dilemmas and unfortunately, at their own choice, they are deprived of the comfort of leaning on one system of truths and universal values. This often results, among other things, in the difficulty of developing a listing of unambiguous and generally accepted rules of conduct free from relativism, in many spheres of human activity. Modern man prefers to escape into the world of imprecise concepts and vague wordings, while distancing themselves from the responsibility for rudimentary issues. These phenomena and processes occur in a particularly clear way in the human-environment relationship.

Throughout history, the nature of these relations has been shaped in a variety of ways, beginning with the primary fear of natural elements, through fascination with the beauty of the natural environment, to the over-exploitation of resources and environmental degradation towards reflection on the need for sustainable development ${ }^{2}$. "The aforementioned man also improves nature, interferes with its laws and secrets, destroys what is natural in the environment, interferes with nature, often destroys it in the name of misunderstood human development" (Kasprzak 2003, 34). This sphere is particularly affected by the stamp of the necessity to make difficult choices between economic, business and environmental values. It is affected by the need of answering the question of how much the value of life and the quality of human health determine the priorities of sustainable development policy planning and how they affect the management model for the use of natural resources and the environmental system.

In what context can the economic value of the environment be considered, and how can the economic categorisation of the environment relate to the understanding of the environment as a higher-order good that has a direct impact on the quality

${ }^{2}$ When considering these types of issues, it is worth to look at the study (Kalinowska 2002). 
of human life, and therefore a good that is in some way beyond the economic assessments (Śleszyński, and Anderson 1996)? The understanding of the human-environment relationship is very diverse in particular currents of philosophical thought and moral views, in religions and in legal and constitutional concepts of the state organisation. These issues are also explored in many scientific fields of various disciplines of ecological science, such as ecology, sozology (active environmental protection science), sozotechnology (environmental conservation and engineering science), sozoeconomy (addresses the economic use of natural resources in order to prevent their degradation), environmental ethics, bioethics, ecophilosophy, ecotheology, environmental policy (Wrzosek 1999, 18; Dołęga 2001, 25), as well as in legal theory, in particular environmental law.

\section{Need for rationality and responsibility}

Contemporary environmental problems should be viewed widely, from the angle of many phenomena, processes and issues, both economic, financial, legal, administrative, systemic, technological, as well as philosophical and moral. The issues concerning the understanding of sustainable development should be placed in this wide context.

The starting point for the considerations are the issues from the borderline of philosophy, morality, economics, finance and law, concerning reasonable management of natural resources, improvement of the state of the natural environment and its protection, as well as regulation and shaping of attitudes and behaviours of people and entities in relation to the natural environment, as well as setting legal boundaries for these behaviours and sanctioning of their crossing. First and foremost, it is necessary to reflect on the essence of man's attitude towards the natural environment at the beginning of the 21st century. As Z. Hull notes, the broadly understood and more and more frequently discussed eco-philosophical issues are becoming particularly important precisely because of social and practical reasons: identifying the current and defining the desired attitude of man (society) to the natural environment is not only cognitive yet existentially important (Hull 2001, 38).

People have a great influence on biological life on Earth and its surroundings. They are able to exert both positive and negative influence, contributing to the degradation of the environment in which they live. The possibility of such a significant influence on the whole planet causes that the interactive human activity should be carefully planned. "Man is the first biological species on Earth capable of modifying the surface of the entire planet, its biosphere, the atmosphere and the climate in a truly profound and global manner" (Kośmicki 2001, 55). The understanding of this fact must be on the basis of the considerations in this work. If one can agree with the fact that man's strongest instinct is the instinct of life and the will to survive, and at the same time it is assumed that man should be aware of the extent and strength of their influence on the surrounding world and at the same time understand that human existence is related to the state of the natural environment, then one should consider the rationality of conduct and man's positive reaction concerning the natural environment as desirable.

In addition to the rationality, the second criterion for human behaviour, while maintaining freedom of choice, should be the responsibility for one's own life, as well as for the life of the global community, and not only responsibility for protecting and preserving life, yet also in the contemporary context - for its proper quality and proper standard. Unfortunately, responsibility is not a "popular" feature of modern man's behaviour. "Man is not satisfied with the fact that they bear so much responsibility, responsibility for the life of the entire mankind. [...] The process of transferring responsibility to someone else is quite common in Western culture" (Kuzior 2001, 294). Therefore, if a person has respect for they own life and the lives of others, they also have the basis for a rational and responsible attitude towards the 
environment. Respect for life as a fundamental and most important value shapes the respect for other values and goods, including nature. Therefore, in countries with authoritarian and totalitarian systems, organised in an undemocratic way, where the authorities have no respect for human life, there are usually no conditions for protecting the environment. Although this is obviously not the hardand-fast principle, as unfortunately, we often observe the issue of an instrumental approach to the use of natural resources and environmental protection in democratic countries as well, however, this is mainly due to a conscious choice of specific socio-economic development policy priorities rather than a lack of respect for human life.

The requirements for the survival of human species include the survival of nature and the conservation of biodiversity. J. Życiński emphasizes that "nature, which was the field of the dramatic struggle for existence for many generations, now reveals its beauty to us clearer than ever [...] Where previous generations saw only the chaos of uncoordinated processes, the fascinating reality of the hidden depths of rational structures is revealing for us" (Życiński 1992, 180). If one accepts rationality and responsibility as the basis for the formation of positive human attitudes towards the surrounding components and elements of nature and natural resources, then one should also consider other conditions of these attitudes, i.e. in particular social, technological, economic, financial and legal conditions.

In the social context, the environment, understood as a good, should not be seen as the property of individuals, yet should be treated as a common good constituting "a function of all those conditions which provide people within society with a life in dignity" (Kasprzak 2003, 57). The willingness to live in a clean environment, to breathe in uncontaminated air and drink clean water is an expression of perceiving the elements of the biosphere as a common good. At the same time, individuals trans- fer these desires to the level of the community, with the lack of personal, individual possibilities to influence the achievement of the desired state of the environment. Therefore, society has a natural right to demand from individuals the behaviour fulfilling the concept of preserving the common good, as well as it is itself the addressee of the demands of individuals.

\section{The idea of quality of live}

It is necessary to return to the previously mentioned idea of the quality of human life as an object of the criterion of human relation to the natural environment. The need to improve the quality of life is frequently used as a justification for public authorities to take specific actions in the field of environmental protection, including in particular investments which result in the development or modernisation of technical infrastructure, e.g. for the treatment and supply of drinking water or waste disposal (Rudnicki 2003, 207). This aspect is particularly highlighted in the programme assumptions of the Polish environmental policy, which emphasises that the superior value in the state's environmental policy is human. This means that the health of society as a whole, the wellbeing of the environment in which local communities live and work, and the life and health of each citizen are the main, indisputable criteria in the implementation of environmental policy at every level: in the workplace and at home, at the local, regional and national level. Therefore, each citizen has the right to demand that the public authority, in its actions for ecological safety, should pursue the ideals of so-called good governance (Niewiadomski 2003, 42; Zoll 2003, 9). In this respect, it is therefore necessary to reflect on what determines the level and standards of quality of life today? Is fulfilling environmental needs (Kasprzak 2003, 57) (collectively understood as the desire to live in an uncontaminated environment and use natural resources) a natural, desirable element of proper quality of life?

The contemporary understanding of the quality of life is determined by the diversi- 
fied standard of living of individual societies. The concept of "quality of life" can be intuitively attributed to developed and affluent societies, as it includes not only a sense of the material basis of existence, yet also the need to satisfy the existential needs of a higher order, e.g. well-organised health care or education system, or living in a clean natural environment. The term "quality of life" in poor, developing societies does not include, in its essence, the desire to satisfy the existential needs of a higher order, rather it is equivalent to the term "survival" or "decent living". It is therefore not easy to define this term unambiguously. It is difficult not to agree with those who, with pessimism and disbelief in the solidarity of the global community, claim that environmental needs are aroused in wealthy and developed societies and that this is where they constitute an important element of the desired quality of life. In addition, there is a difference between the perception of environmental needs in a wealthy society, which is aware of the degree of environmental degradation and has a highly developed general environmental awareness, and the perception of these needs in a poor society, unaware of the environmental risks and degradation of the surrounding environment. Therefore, attention should be paid to the problem of equitable participation of societies in the environmental sphere (Carley, and Spapens 2000, 85).

The state of the natural environment strongly influences the satisfaction of existential human needs and is connected with ecological needs, which can be characterized as requirements relating to biological, physical, chemical and technological properties of individual elements of the environment. In order to achieve a satisfactory standard of living and quality of life, people must choose between various goods. Unfortunately, environmental goods are frequently treated as the last in the hierarchy and must take second priority to the material well-being or social security. Treating environmental goods as the last category of the needs, usually in a way that is unnoticeable in the short term, leads to permanent and negative changes in the direct environment of human life and has a negative impact on their health. As S. Kasprzak points out, "the depravity of environmental needs, a kind of degeneration of human expectations and intentions, frequently leads to temporary or permanent loss of health and even life"(Carley, and Spapens 2000, 55).

For this reason, environmental awareness is an extremely important prerequisite for the selection and implementation of ecological needs as one of the primary existential needs with a significant impact on the quality of life. The aim of developing people's environmental awareness is to develop behaviours that are oriented towards environmental protection both in an individual and global dimension, concerning the society as a whole and its individual groups, e.g. consumers or entrepreneurs. The development of environmental awareness and pro-ecological behaviour in different societies depends on general cultural and social and economic development (Möller 2004a, 133). In modern, highly developed societies, there are significant untapped potentials which, through properly implemented environmental education and information policy, may contribute to the development of appropriate, pro-ecological models of social and consumer behaviour, economic activities and good manufacturing practices. Highly developed environmental awareness and positive and environmentally friendly attitudes, behaviours and activities, which constitute important foundations for sustainable development, require well planned and consistently implemented education including various areas of environmental protection. The education system must be organised by both public and private institutions and NGOs (Paczuski 2002, 293). Education must be accompanied by a well-structured policy of information about the environment and its state. Only such comprehensive measures can contribute to the development and dissemination of sustainable, pro-ecological patterns of behaviour and attitudes of politicians, entrepreneurs, consumers and the 
general public. Education, information and knowledge of the environment are supported by the Aarhus Convention (Convention 1998) on access to information, public participation in decision-making and access to justice in environmental matters.

All human activities in the natural environment entail specific transformations, the nature of which depends on the type of human activity, its intensity and compliance with applicable standards. The issue of human interference in the natural environment is connected with a fundamental dispute concerning the definition of priorities for civilization development, in particular, when progress pursued allegedly in the name of human good started to directly threaten human health and life (Karaczun, and Ludeka 1996, 263). One of the most important environmental and civilisation problems is that today's economic development and scientific and technological progress are closely interdependent and interact with each other. When implementing an economic development plan using available technology and engineering, the environment is frequently over-exploited (Weizsacker, Lovins, and Lovins 1999). As a result of this exploitation, humans receive basic production materials and at the same time contribute to a number of environmental contaminants. The structure of this contamination resulting from exploitation and production activities is the result of both the economic activity and the technological level in particular fields of activity (Ciborowski 1981, 80-82; Dobrzański, Dobrzańska, and Kiełczewski 1997, 131-132).

In addition to economic aspects, the environment is also influenced by social issues. The special attention paid to the environmental aspect of social relations is justified by the fact that permanent changes in the environment also change the attitude of society towards nature. According to $\mathrm{K}$. Gorka, this leads to the conclusion that the interaction between society and nature must be studied not only in a static but also in a dynamic system which enables knowledge of both the very essence of this activity and the direction of its evolution (Górska, Poskrobko, and Radecki 1998, 16-20).

Is this development intended to be subordinate to the economy, or is the axis of this development to be the protection and preservation of environmental resources? Is it perhaps most reasonable to balance economic, social and environmental objectives? (Żylicz 1990) The issue presented in such a way indicates its importance in the life of the global community and provokes reflection for many years now (Czaja, Fiedor, and Jakubczyk 1992).

As Michajłow emphasises, the key issue is to precisely identify the causes and effects, as well as the further consequences of the changes occurring in the environment as a result of social and economic activity of man. The results of the assessments should be used to identify effective ways of preventing or reducing negative effects on the environment and, above all, on humans (Michajłow 1979, 113-114).

The difficulty of solving these dilemmas on a global scale is demonstrated, for example, by the fact that international environmental conventions are only signed in areas that are fully consistent with the national interests of individual countries (Budnikowska 1998, 156-159).

Therefore, the compromise between the economy and the environment should be based on a comprehensive analysis of the problem, taking into account both fundamental natural, social and economic laws (Machowski 2003, 65-66).

\section{Conclusion. Polish way of sustainable development}

The Second National Environmental Action Plan of Poland (Druga Polityka Ekologiczna Państwa - II PEP) $)^{3}$ emphasises

${ }^{3}$ The source literature notes that the II PEP was adopted by the Council of Ministers on 13 June 2000 and then adopted by the Sejm on 22 August 2001. Article 10(2) of the Act of 27 July 2001 on the introduction of the Environmental Protection Law, the Act on Waste Management and the amendments to certain acts (Journal of Laws of 2001 No. 100, item 1085 ) ordered the development of a new environmental policy, specifying the deadline of 31 December 2002. However, PEP II was adopted before the 
that man and their activities are closely linked to the environmental system. Maintaining balance in this system requires coherent and joint management of the access to environmental resources as well as elimination and prevention of negative effects of economic activity on the environment (environmental protection) and reasonable use of natural resources (water management, forestry, protection and use of raw materials and soil resources, spatial planning). This should be reflected in appropriate management structures at the national, regional and local level and in the distribution of competences, tasks and available procedures that ensure that environmental policy objectives at each level are based on proper identification of needs and that the measures to fulfil them are primarily based on environmental and economic efficiency criteria. This is the only method of ensuring environmental safety for citizens ${ }^{4}$.

Environmental safety can be understood both as a functional objective of environmental policy and as a legal norm, existing both in domestic and international law, imposing on public authorities the obligation to ensure environmental safety for present and future generations in accordance with the principle of sustainable development.

entry into force of the Environmental Protection Law of 27 April 2001 (Journal of Laws Of 2001, No. 62, item 627, as amended). Therefore, as M.Bar notes, it should be considered whether the II PEP was fully compliant with the requirements of the said Act. M. Bar emphasises that the PEP II includes the period from 2000 to 2025, whereas according to Article 14 (2) of the Environmental Protection Law, environmental policy is adopted for four years, whereas the measures provided for therein include a further four years; (Radziszewski 2003).

${ }^{4}$ See Resolution of the Sejm of the Republic of Poland of 22 August 2001 on the new state environmental policy. Interestingly, this resolution was not published in Monitor Polski. The experts of the BSiE Chancellery of the Sejm of the Republic of Poland state that this resolution only referred to the document on the new environmental policy adopted earlier by the Council of Ministers.

\section{Bibliography}

Agenda 1998 - Agenda 21. Progress Report 1992-1998. IInd Updated Edition, Warsaw.

Budnikowski, Adam. 1998. Ochrona środowiska jako problem globalny. Warszawa: Polskie Wydawnictwo Ekonomiczne.

Carley, Michael, and Philippe Spapens. 2000. Dzielenie się światem. Zrównoważony sposób życia $i$ globalnie sprawiedliwy dostęp do zasobów naturalnych w XXI wieku. Białystok-Warszawa: Wydawnictwo Instytutu na Rzecz Ekorozwoju.

Ciborowski, Adolf. 1981. Polityka ksztattowania środowiska. Warszawa: Wiedza Powszechna.

Convention 1998 - Convention on Access to Information, Public Participation in Decision-Making and Access to Justice in Environmental Matters, concluded on 25 June 1998 in Aarhus (Dz. U. 2001 nr 89, poz. 970).

Czaja, Stanisław, Bogusław Fiedor, and Zbigniew Jakubczyk. 1992. Ekologiczne uwarunkowania wzrostu gospodarczego w ujęciu współczesnej teorii ekonomii. Białystok-Kraków: Wydawnictwo Ekonomia i Środowisko.

Dobrzański, Grzegorz, Bożena Dobrzańska, and Dariusz Kiełczewski. 1997. Ochrona środowiska przyrodniczego. Białystok: Wydawnictwo Ekonomia i Środowisko.

Dołęga, Józef M. 2001. „Z filozofii nauk ekologicznych." W Ochrona środowiska społeczno-przyrodniczego $w$ filozofii $i$ teologii, red. Józef M. Dołęga, Jacek Czartoszewski, Antoni Skowroński. Warszawa: Wydawnictwo UKSW.

Górka, Kazimierz, Bazyli Poskrobko, and Wojciech Radecki. 1998. Ochrona środowiska. Problemy społeczne, ekonomiczne i prawne. Warszawa: Polskie Wydawnictwo Ekonomiczne.

Hull, Zbigniew. 2003. „O dwóch sposobach pojmowania i uprawiania filozofii ekologii." W Ochrona środowiska społeczno-przyrodniczego w filozofii i teologii, red. Józef M. Dołęga, Jacek Czartoszewski, Antoni Skowroński. Warszawa: Wydawnictwo UKSW.

Jendrośka, Jerzy, and Magdalena Bar. 2001. Ustawa Prawo ochrony środowiska. Komentarz. Wrocław: Wydawnictwo Centrum Prawa Ekologicznego.

Kalinowska, Anna. 2002. Ekologia - wybór na nowe stulecie. Warszawa: Agencja Reklamowo-Wydawnicza A. Grzegorczyk. 
Karaczun Zbigniew, and Leonard Indeka. 1996. Ochrona środowiska. Warszawa: Aries.

Kasprzak, Sylwester. 2003. Normatywny wymiar ekologicznych $i$ sozologicznych idei $w$ systemie prawa państwowego i kościelnego. Lublin: Wydawnictwo Bamka.

Kośmicki, Eugeniusz. 2001. „Problem odpowiedzialności człowieka za ewolucję." W Ochrona środowiska społeczno-przyrodniczego $w$ filozofii i teologii, red. Józef M. Dołęga, Jacek Czartoszewski, Antoni Skowroński. Warszawa: Wydawnictwo UKSW.

Kuzior, Aleksandra. 2001. „Wolność wyboru a problem odpowiedzialności - rozważania Ericha Fromma." W Ochrona środowiska spoteczno-przyrodniczego $w$ filozofii $i$ teologii, red. Józef M. Dołęga, Jacek Czartoszewski, Antoni Skowroński. Warszawa: Wydawnictwo UKSW.

Leroy, Pieter. 2000. "Political Modernisation and the Renewal of Environmental Policy Arrangements." In Sustainable Development - an European View, edited by Marzenna R. Dudzińska, Artur Pawłowski. Lublin: Wydawnictwo PAN.

Machowski, Jacek. 2003. Ochrona środowiska. Prawo i zrównoważony rozwój. Warszawa: Wydawnictwo Akademickie ŻAK.

Maśniak, Dorota. 2003. Ubezpieczenia ekologiczne. Kraków: Zakamycze.

Michajłow, Włodzimierz. 1979. Człowiek $i$ środowisko. Wrocław: Ossolineum.

Möller, L. 2004a. „Proekologiczna edukacja oraz informacja o środowisku jako główne składniki świadomości ekologicznej." W Międzynarodowe zarzadzanie środowiskiem. Tom I, Interdyscyplinarne założenia proekologicznego zarzadzania przedsiębiorstwem. Studia Ekonomiczne, red. Matthias Kramer, Maria Urbaniec, i Andrzej Kryński. Warszawa: C. H. Beck.

Möller, L. 2004b. „Znaczenie polityki ochrony środowiska $\mathrm{z}$ punktu widzenia przedsiębiorstw w aspekcie międzynarodowym." W Międzynarodowe zarzadzanie środowiskiem. Tom I, Interdyscyplinarne założenia proekologicznego zarzadzania przedsiębiorstwem. Studia Ekonomiczne, red. Matthias Kramer, Maria Urbaniec, i Andrzej Kryński. Warszawa: C. H. Beck.
Niewiadomski, Zygmunt. 2003. „Prawo do dobrej administracji - aspekty procesowe, ustrojowe i materialne." Biuletyn Biura Informacji Rady Europy nr 4.

Paczuski, Ryszard. 2002. „O niedostatku nauczania prawa ochrony środowiska w Polsce." W Zasada zrównoważonego rozwoju w prawie i praktyce ochrony środowiska, red. Kazimierz Równy, Jarosław Jabłoński, 293295. Warszawa: Wydawnictwo PWSBiA.

Przyborowska-Klimczak, Anna. 2004. Ochrona przyrody. Studium prawnomiędzynarodowe. Lublin: Wydawnictwo UMCS.

Radziszewski, Edward. 2003. Prawo ochrony środowiska. Przepisy i komentarz. Warszawa: LexisNexis.

Rudnicki, Maciej. 2003. „Odpowiedzialność władz publicznych za realizację zadań w dziedzinie ochrony środowiska." W Prawość i Godność, Ksiegga pamiatkowa w 70 rocznice urodzin Profesora Wojciecha Łaczkowskiego, red. Andrzej Gomułowicz, Sławomir Fundowicz, Ferdynand Rymarz, $207-$ 216. Lublin: Wydawnictwo KUL.

Śleszyński, Jerzy, and Glen Anderson. 1996. Ekonomiczna wycena środowiska przyrodniczego. Białystok: Wydawnictwo Ekonomia i Środowisko.

Weizsacker, Ernst Urlich von, Amory B. Lovins, and L. Hunter Lovins. 1999. Mnożnik cztery, podwojony dobrobyt - dwukrotnie mniejsze zużycie zasobów naturalnych. Toruń: Wydawnictwo Rolewski.

Wrzosek, Stanisław. 1999. Zarzadzanie środowiskiem przez administracje publiczna w Polsce. Białystok: Wydawnictwo Politechniki Białostockiej.

Zoll, Andrzej. 2003. „Dobra administracja jako prawo obywatela." Biuletyn Biura Informacji Rady Europy, no 4.

Życiński, Józef. 1992. Utaskawienie natury. Kraków: Znak.

Żylicz, Tomasz. 1990. Ekonomia wobec problemów środowiska przyrodniczego. Warszawa: PWN. 